\title{
Anurans of Sete Cidades National Park, Piauí state, northeastern Brazil
}

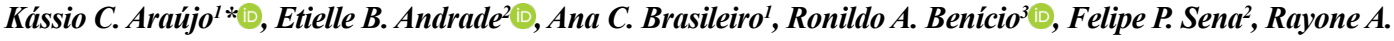 \\ Silva2 ${ }^{\circledR}$, Antonia Joyce S. Santos ${ }^{2}$, Claylton A. Costa ${ }^{2} \&$ Robson W. Ávila \\ ${ }^{1}$ Universidade Federal do Ceará, Centro de Ciências, Programa de Pós-Graduação em Ecologia e Recursos \\ Naturais, Bloco 902, Campus do PICI, Av. Humberto Monte, s/n, 60455-760, Fortaleza, CE, Brasil. \\ ${ }^{2}$ Instituto Federal de Educação, Ciência e Tecnologia do Piauí, Grupo de Pesquisa em Biodiversidade e \\ Biotecnologia do Centro-Norte Piauiense, Campus Pedro II, 64255-000, Pedro II, PI, Brasil. \\ ${ }^{3}$ Universidade Regional do Cariri, Laboratório de Herpetologia, Programa de Pós-Graduação em Diversidade \\ Biológica e Recursos Naturais, 63105-000, Crato, CE, Brasil.
}

*Corresponding author: Kássio C. Araújo, e-mail: kassio.ufpi@gmail.com

ARAÚJO, K.C., ANDRADE, E.B., BRASILEIRO, A.C., BENÍCIO, R.A., SENA, F.P., SILVA, R.A., SANTOS, A.J.S., COSTA, C.A., ÁVILA, R.W. Anurans of Sete Cidades National Park, Piauí state, northeastern Brazil. Biota Neotropica 24(4): e20201061. https://doi.org/10.1590/1676-0611-BN-2020-1061

\begin{abstract}
The Sete Cidades National Park is located in the Brazilian municipalities of Piracuruca and Brasileira, Piauí state, in a transitional zone between the Caatinga and Cerrado biomes. Studies on its herpetofauna were limited to anuran distribution notes and a snake checklist. Thus, here we present an unpublished species list of anurans from Sete Cidades National Park, Piauí state, northeastern Brazil. We recorded one of the two highest species richness for all northeastern National Parks, and also increased the geographic distribution of one species in the state of Piauí. Most species observed are common of both Caatinga and Cerrado biomes or have wide distribution in Brazil. The anuran assemblage of Sete Cidades National Park is more similar to those registered at the Delta do Parnaíba Environmental Protection Area, Ceará, Piauí and Maranhão states, and Ubajara National Park, Ceará state. These results increase our knowledge on anuran diversity in northeastern Brazil, providing basic information for management and conservation actions of an important Brazilian National Park.
\end{abstract}

Keywords: amphibians; ecotones; herpetofauna; checklist; conservation.

\section{Anuros do Parque Nacional de Sete Cidades, estado do Piauí, nordeste do Brasil}

Resumo: O Parque Nacional de Sete Cidades está localizado nos municípios de Piracuruca e Brasileira, Estado do Piauí, em uma zona de transição entre os biomas Caatinga e Cerrado. Os estudos sobre sua herpetofauna estão limitados a notas de distribuição de anfíbios e um inventário de serpentes. Portanto, aqui apresentamos uma lista inédita de espécies de anuros do Parque Nacional de Sete Cidades, Estado do Piauí, Nordeste do Brasil. Nós registramos uma das duas maiores riquezas de espécies dentre todos os Parques Nacionais do Nordeste, além de aumentar a distribuição geográfica de uma espécie para o estado. A maioria das espécies observadas são comuns em ambos os biomas da Caatinga e Cerrado ou têm ampla distribuição no Brasil. A assembleia de anuros do Parque Nacional de Sete Cidades é mais similar àquela registrada na Área de Proteção Ambiental do Delta do Parnaíba, estados do Ceará, Piauí e Maranhão, e no Parque Nacional de Ubajara, estado do Ceará. Estes resultados aumentam nosso conhecimento sobre a diversidade de anuros no Nordeste do Brasil, fornecendo subsídios para ações de gestão e conservação de um importante Parque Nacional do Brasil.

Palavras-chave: anfíbios; ecótonos; herpetofauna; lista de verificação; conservação. 


\section{Introduction}

The Brazilian Conservation Units system has 73 National Parks (PARNAs), covering about 75 million hectares, almost $10 \%$ of the Brazilian territory (ICMBio 2016). These National Parks are fundamentally important for biodiversity conservation because they protect natural environments and their resources, fauna, and flora. In addition, they provide subsidies to scientific research, environmental education and sustainable tourism (Brito \& Câmara 1998).

There are 20 National Parks in Northeastern Brazil, of which four (Serra da Capivara National Park - SCaNP, Sete Cidades National Park - SCNP, Serra das Confusões National Park - SCoNP and Nascentes do Rio Parnaíba National Park - NRPNP) are located in the state of Piauí (ICMBio 2016). These four national parks have a total area of approximately $11.817,46 \mathrm{~km}^{2}$, representing about $4.7 \%$ of the state of Piauí, and present environments with characteristics of different biomes, forming a complex landscape with high biodiversity (Matos et al. 2010).

The state of Piauí has extensive transition areas covered with ecotonal formations (about $20 \%$ of the state). In the state's northern portion transitional areas between the Amazon rainforest and Caatinga are found, represented by deciduous and semi-deciduous forests, and babassu and carnaúba palm forests. The south-central portion is characterized by the contact between Caatinga (about $37 \%$ of the state) and Cerrado (around $33 \%$ of the state), represented by typical open area vegetation adapted to water deficits (Farias \& Castro 2004). The ecotones or transitional zones in northeastern region of Brazil harbor rich anuran faunas, despite these areas having been studied only recently (e.g. Magalhães et al. 2013, Silva et al. 2013, Benício et al. 2014, Dal Vechio et al. 2016, Matavelli et al. 2019). This diversity of contrasting environments from neighboring biomes likely allow the coexistence of high faunistic and floristic diversities that need to be studied further.
Recently, there has been an increase in studies of amphibians from Piauí state, such as the description of new species (e.g. Maciel et al. 2015), distributional records (e.g. Andrade et al. 2011, Benício et al. 2011, 2012, Leite Jr. et al. 2008, Macedo et al. 2011, Vasconcelos et al. 2014, Santos et al. 2019), ecological relations and checklists (i.e. Loebmann \& Mai 2008, Dal Vechio et al. 2013, 2016, Andrade et al. 2014, 2016, Benício et al. 2014, 2015, Araújo et al. 2018). Despite the availability of a compilation of amphibian species published for Piauí state (Roberto et al. 2013), there is still a lack of studies in some regions. For example, inventories evaluating species richness of anurans have been published for only half of the National Parks from Piauí (i.e. Serra das Confusões and Serra da Capivara National Parks) (Cavalcanti et al. 2014, Dal Vechio et al. 2016).

The Sete Cidades National Park (SCNP) was created in 1961 for the preservation and conservation of natural resources, flora, and fauna of this ecotonal region. However, herpetofaunal studies in the region were limited to amphibian distribution notes (Annunziata et al. 2007, Vasconcelos et al. 2014) and a snake checklist (Rocha \& Prudente 2010). Thus, even after nearly 60 years of its creation, the distribution pattern of amphibians (or even a list of species) remains mostly unknown in this region. Herein, we provide a checklist of anuran species from the Sete Cidades National Park, comparing its richness and composition with other Protected areas in Caatinga and Cerrado biomes.

\section{Material and methods}

\section{Study area}

We conducted the study in Sete Cidades National Park (SCNP), located in the northern region of the state of Piauí, northeastern Brazil $\left(04^{\circ} 05^{\prime}-04^{\circ} 15^{\prime} \mathrm{S}\right.$ and $41^{\circ} 30^{\prime}-41^{\circ} 45^{\prime} \mathrm{W}$, WGS 84 datum, Figure 1$)$.
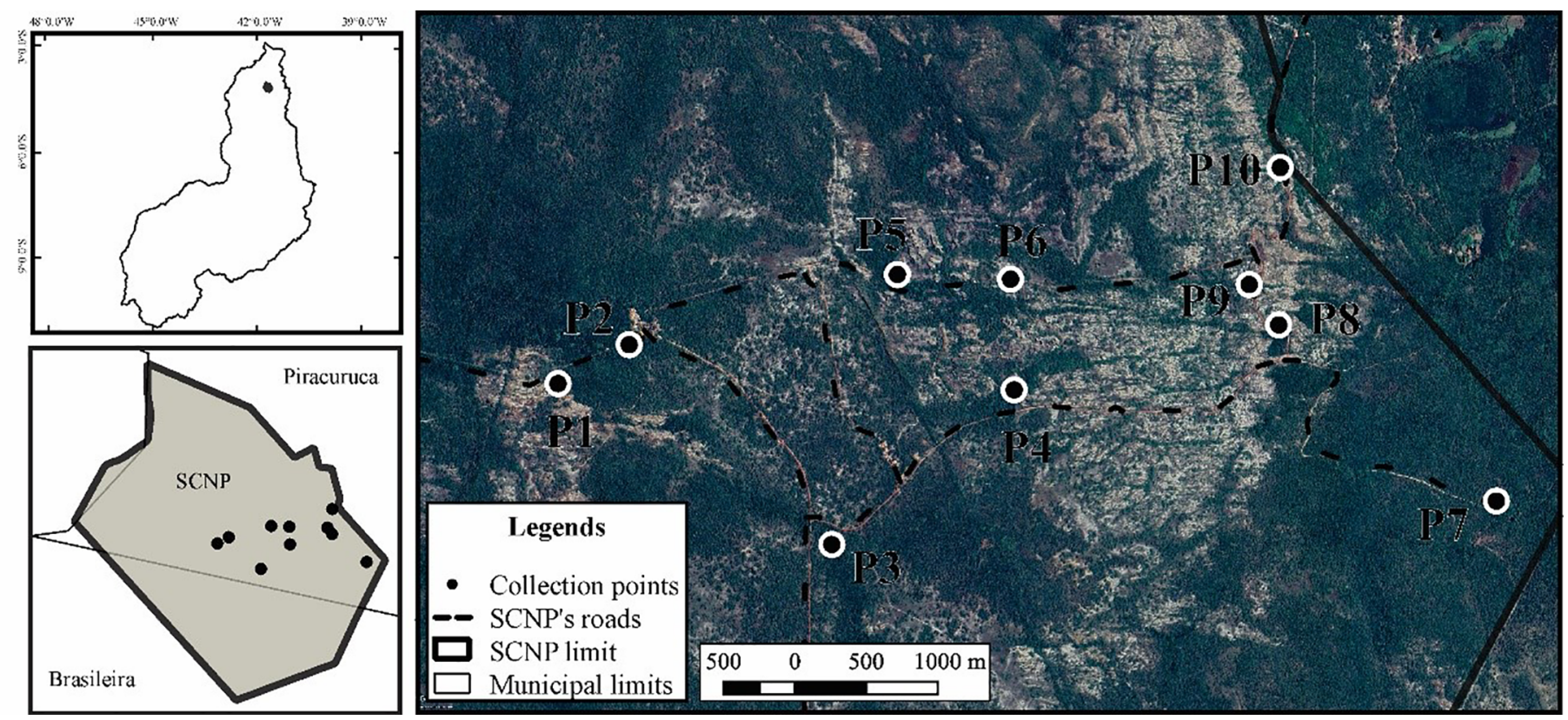

Figure 1. Location map of the Sete Cidades National Park (SCNP), Piaui state, northeastern Brazil, showing the collection points within the different types of environments in the park. 
Covering approximately 6.221 ha between the Brazilian municipalities of Piracuruca and Brasileira, the SCNP is located in a transitional area between the Ibiapaba plateau and the coastal plain, with a relief formed by sedimentary basins and altitudes ranging from 100 to $300 \mathrm{~m}$ above sea level (Afonso et al. 2008). Its vegetation is typical of a transition zone, with Caatinga patches inserted in Cerrado vegetation, on different soil types: Red Latosols, Quartzerenic Latosols, Lithic Latosols and Planosols (Della-Favera 2002, Oliveira et al. 2010, Lopes 2011). These physical-natural aspects allow the formation of six different vegetation types at SCNP: typical cerrado, covering $37.6 \%$ of the total area, cerradão with $24.3 \%$, campo limpo with $14.3 \%$, cerrado rupestre with $10.5 \%$ of SCNP area, semi-deciduous forest with $8.4 \%$, and flooded gallery forest covering only $3.3 \%$ of the area (Ribeiro \& Walter 1998). The SCNP region has a dry semi humid tropical climate (Aw' type), with average annual rainfall ranging from $1.300 \mathrm{~mm}$ to $1.500 \mathrm{~mm}$. It has an average annual temperature of $33.6^{\circ} \mathrm{C}$, with minimum temperatures of $21.8^{\circ} \mathrm{C}$ in February, and maximum temperatures of $35.0^{\circ} \mathrm{C}$ in October (Castro \& Costa 2007).

\section{Anuran sampling}

We conducted fieldwork in two distinct rainy periods distributed in 2018 and 2019, totaling 19 sampling days. Two sampled methods were performed: the first sampling campaign was carried out for 11 consecutive days in May 2018, from the $16^{\text {th }}$ to the $26^{\text {th }}$, while the second campaign consisted of monthly visits between January and May 2019, lasting two consecutive days each. It is important to point out in both campaigns we used auditory census and active visual searches (Crump \& Scott Jr. 1994) in different environments used by anurans within SCNP (Table 1; Figure 2), searching species on soil, water, and terrestrial and aquatic vegetation. These methods are indicated for inventory studies because are inexpensive and efficient to record the largest species number in the shortest time (Valdujo et al. 2009, Andrade et al. 2017). In both campaigns four researchers carried out field activities, starting around 18:00 $\mathrm{h}$ and ending at 00:00 $\mathrm{h}$, resulting in the total sampling effort of $108 \mathrm{~h} /$ person. The collection locations were random and chosen according to the species' vocalization activities.
We deposited voucher specimens in the Herpetological collection of the Universidade Regional do Cariri (URCA-H) and the Coleção Biológica of the Instituto Federal de Educação, Ciência e Tecnologia do Piauí, Campus Pedro II (CBPII) and tissue samples in Tissue collection of the Universidade Regional do Cariri (URCA-G). Anuran nomenclature follows Carvalho et al. (2020), Frost (2020), and Mângia et al. (2020).

\section{Statistical analyses}

We evaluated the efficiency of anuran sampling methods in SCNP by using sample-based accumulation curves (Gotelli \& Colwell 2001) with 1000 randomizations from an incidence matrix. Each night of observation corresponded to a sample, resulting in 19 samples. In addition, we calculated the expected species richness using the nonparametric estimators Chao 2 and Jackknife 1 (Magurran \& McGill 2011), with 100 randomizations.

Considering SCNP is located in a transitional zone between Caatinga and Cerrado, we compared its anuran species richness with other protected areas located in both biomes and calculated the Local Contribution to Beta Diversity - LCBD (sensu Legendre \& De Cáceres 2013) to evaluate the variation in species composition among different sites. The LCBD allows us to evaluate which component of beta diversity (turnover or nestedness) best explain the variation in species composition (Legendre 2014). For this analysis, we constructed a matrix with presence and absence data for 181 anuran species, excluding species without specific identification ("gr.", "aff." and "sp.") and considering only species with identification to be confirmed ("cf."). We obtained the LCBD values using the Jaccard dissimilarity index of the Baselga family for presenceabsence data (Legendre 2014). In addition, we performed the Jaccard Similarity coefficient (J'; Magurran \& McGill 2011) with a subsequent cluster analysis by Unweighted Pair Group Average Method (UPGAM), to illustrate the similarity between anurans richness of SCNP and other protected areas from Caatinga and Cerrado biomes. To investigate the relationship between the amphibian species richness similarity and the protected areas geographical distance, we measure the geographical distances between the above-cited areas using ArcGIS software (Esri 2008) and performed a Mantel test (Manly 1994), with 10.000 permutations.

Table 1. Environmental description of the sampled habitats in the Sete Cidades National Park (SCNP), Piauí state, northeastern Brazil. The vegetation was classified according to Oliveira et al. (2010).

\begin{tabular}{|c|c|c|c|}
\hline \multirow[t]{2}{*}{ Collection points } & \multicolumn{2}{|c|}{ Geographical coordinates } & \multirow[t]{2}{*}{ Description } \\
\hline & $\mathbf{S}$ & W & \\
\hline P1 & $4^{\circ} 06^{\prime} 08.82^{\prime \prime}$ & $41^{\circ} 42^{\prime} 51.21^{\prime \prime}$ & Temporary puddles in areas of Cerrado grassland (cerrado rupestre) formed on the rocky outcrop. \\
\hline P3 & $4^{\circ} 06^{\prime} 36.10^{\prime \prime}$ & $41^{\circ} 42^{\prime} 04.70^{\prime \prime}$ & $\begin{array}{l}\text { Large temporary lake formed in an area of cerrado sensu stricto (cerrado típico) on the side of } \\
\text { the access road to the park. }\end{array}$ \\
\hline P6 & $4^{\circ} 05^{\prime} 51.11^{\prime \prime}$ & $41^{\circ} 41^{\prime} 34.36 "$ & Temporary stream formed in a cerrado sensu stricto area (cerrado típico). \\
\hline P7 & $4^{\circ} 06^{\prime} 28.73 "$ & $41^{\circ} 40^{\prime} 11.86^{\prime \prime}$ & Temporary waterfall formed in an area of semi-deciduous dry forest (Mata seca semidecídua). \\
\hline P8 & $4^{\circ} 05^{\prime} 58.86^{\prime \prime}$ & $41^{\circ} 40^{\prime} 48.81^{\prime \prime}$ & Temporary puddles formed in a cerrado sensu stricto area (cerrado típico). \\
\hline P9 & $4^{\circ} 05^{\prime} 52.02^{\prime \prime}$ & $41^{\circ} 40^{\prime} 53.83^{\prime \prime}$ & Extensive temporary pond formed in a cerrado sensu stricto area (cerrado típico). \\
\hline
\end{tabular}




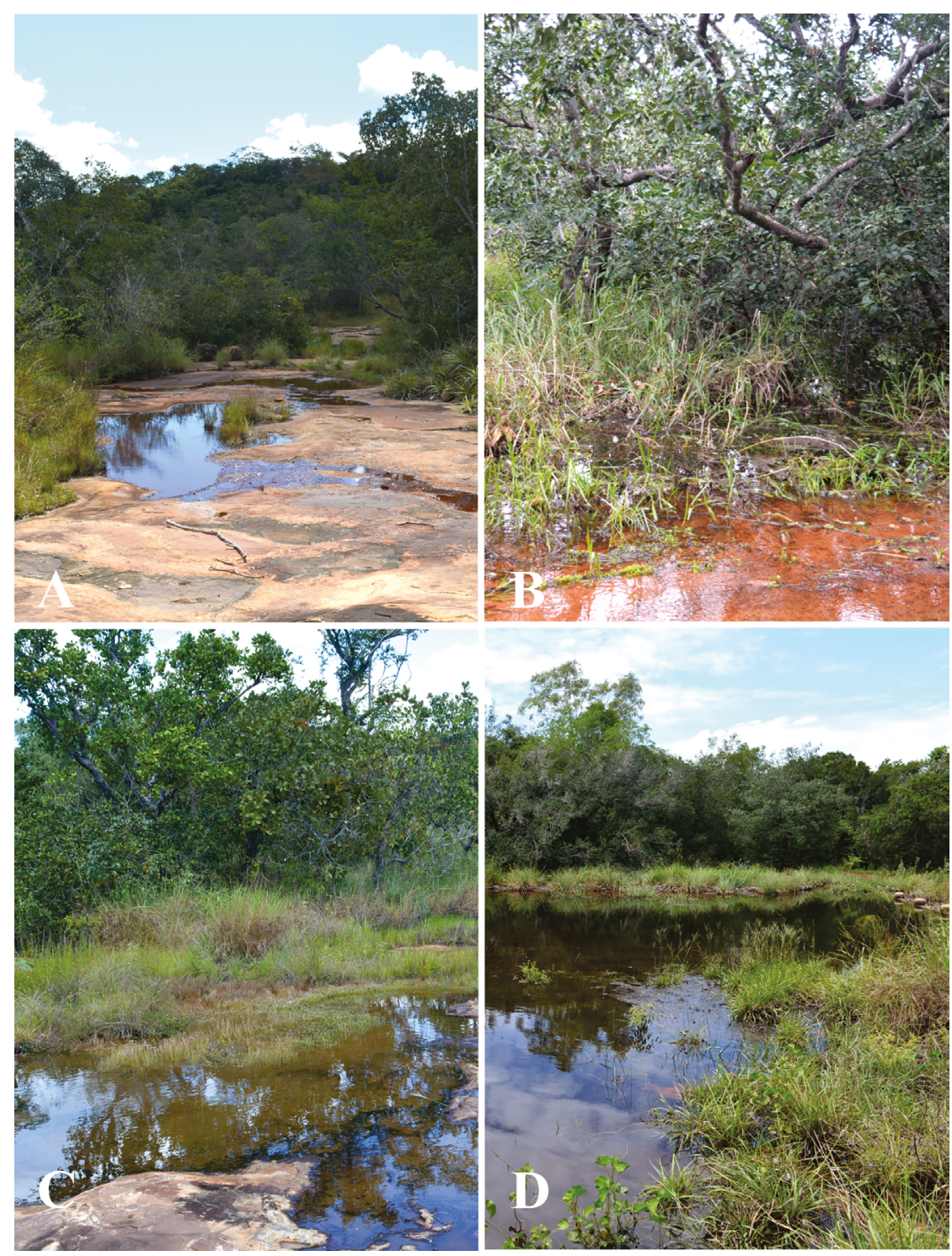

Figure 2. Sampled environments in the Sete Cidades National Park (SCNP), Piauí state, northeastern Brazil. Images A, B, C, and D represent, respectively, the collection points $\mathrm{P} 1, \mathrm{P} 3, \mathrm{P} 4$, and $\mathrm{P} 9$.

We obtained anuran richness data from the following checklists conducted in 28 protected areas (Figure 3): Caatinga (12 protected areas) - Catimbau National Park - CatNP, state of Pernambuco (Pedrosa et al. 2014), Seridó Ecological Station - SerES, state of Rio Grande do Norte (Caldas et al. 2016), Delta do Parnaíba Environmental Protection Area - DPEPA, states of Maranhão and Piauí (Loebmann \& Mai 2008, Andrade et al. 2016, Araújo et al. 2018), Serra das Confusões National Park - SCoNP and Uruçuí-Una Ecological Station-UUES, both in state of Piauí (Dal Vechio et al. 2013, 2016), Lençóis Maranhenses National Park - LMNP, state of Maranhão (Miranda 2007), Chapada do Araripe Environmental Protection Area - ChpEPA, Ubajara National Park UbaNP and Aiuaba Ecological Station - AuES, state of Ceará (Ribeiro et al. 2012, Costa et al. 2018, Castro et al. 2019), Chapada Diamantina National Park -CDNP and Raso da Catarina Ecological Station-RcatES, state of Bahia (Garda et al. 2013, Magalhães et al. 2015); and Cerrado (16 protected areas) - Chapada dos Veadeiros National Park - ChvNP, Emas National Park - EmNP, Altamiro de Moura Pacheco State Park - AltSP, Serra de Caldas Novas State Park - SCalSP, IBGE Ecological
Reserve - IbgER, Lago do Cedro Extractive Reserve - LcdER, and Silvânia Nacional Forest - SilNF, state of Goiás (Kopp et al. 2010, Colli et al. 2011, Morais et al. 2012, Melo et al. 2013, Santoro and Brandão 2014, Ramalho et al. 2018, 2019), Santuário do Caraça RPPN - StRPPN, Peti Environmental Station - PetES, State of Minas Gerais (Canelas and Bertoluci 2007, Bertoluci et al. 2009), Serra da Bodoquena National Park - SrBNP, state of Mato Grosso do Sul (Uetanabaro et al. 2007), Assis Ecological Station - AsES, Jataí Ecological Station - JatES, Furnas de Bom Jesus State Park - FurSP, and Itirapina Ecological Station - ItiES, state of São Paulo (Brasileiro et al. 2005, Araujo et al. 2009, Prado et al. 2009, Ribeiro-Júnior \& Bertoluci 2009, Araújo \& Almeida-Santos 2011), Serra Geral do Tocantins Ecological Station - StoES, states of Bahia and Tocantins (Valdujo et al. 2011), Mirador State Park - MirSP, state of Maranhão (Andrade et al. 2017). Due to the low representativeness of amphibians in the Serra da Capivara National Park, we did not include in our analysis the checklist carried out by Cavalcanti et al. (2014) to avoid a trend in the comparison among species composition caused by the large difference in the number of species. 


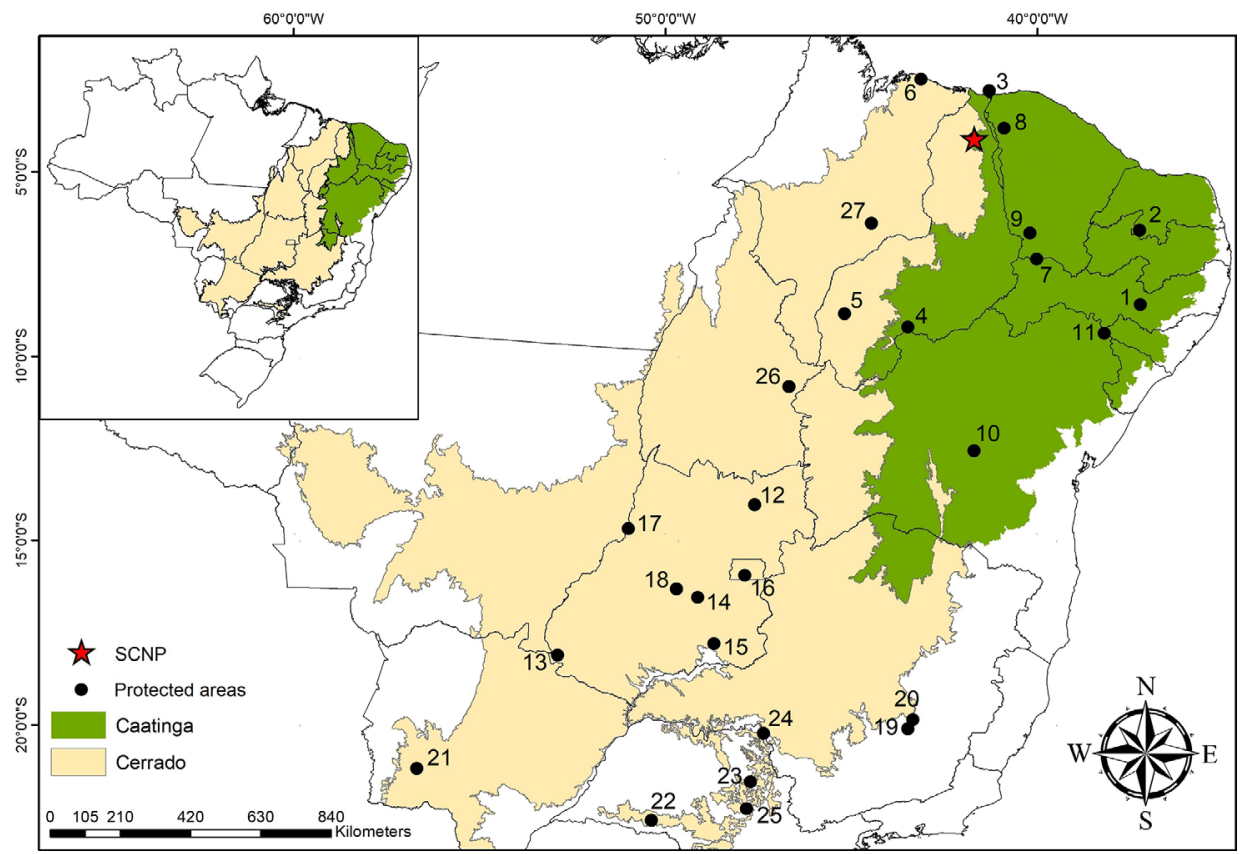

Figure 3. Geographical location of the Sete Cidades National Park (SCNP; red star) and other protected areas (black circles) in Caatinga biome: 1 - Catimbau National Park (CatNP), 2 - Seridó Ecological Station (SerES), 3 - Delta do Parnaíba Environmental Protection Area (DPEPA), 4 - Serra das Confusões National Park (SCoNP), 5 - Uruçuí-Una Ecological Station (UUES), 6 - Lençóis Maranhenses National Park (LMNP), 7 - Chapada do Araripe Environmental Protection Area (ChpEPA), 8 Ubajara National Park (UbaNP), 9 - Aiuaba Ecological Station (AuES), 10 - Chapada Diamantina National Park (CDNP), 11 - Raso da Catarina Ecological Station (RcatES); and Cerrado biome: 12 - Chapada dos Veadeiros National Park (ChvNP), 13 - Emas National Park (EmNP), 14 - Altamiro de Moura Pacheco State Park (AltSP), 15 - Serra de Caldas Novas State Park (SCalSP), 16 - IBGE Ecological Reserve (IbgER), 17 - Lago do Cedro Extractive Reserve (LcdER), 18 - Silvânia Nacional Forest (SilNF), 19 - Santuário do Caraça RPPN (StRPPN), 20 - Peti Environmental Station (PetES), 21 - Serra da Bodoquena National Park (SrBNP), 22 - Assis Ecological Station (AsES), 23 - Jataí Ecological Station (JatES), 24 - Furnas de Bom Jesus State Park (FurSP), 25 - Itirapina Ecological Station (ItiES), 26 - Serra Geral do Tocantins Ecological Station (StoES), 27- Mirador State Park (MirSP).

We evaluate anuran species distribution and association with Brazilian biomes (IBGE 2019) from literature records (i.e. Roberto et al. 2013, Andrade et al. 2017, Araújo et al. 2018, Frost 2020) and the amphibian conservation status is according to IUCN (2020). All diversity metrics and similarity analysis were performed using the packages adespatial (Dray et al. 2019), BiodiversityR (Kindt and Coe 2005), and Vegan (Oksanen et al. 2016) for R 5.6.1 (R Core Team 2019).

\section{Results}

We recorded 30 anuran species in the Sete Cidades National Park (SCNP), distributed in six families: Bufonidae (2 spp.), Hylidae (11 spp.), Leptodactylidae (13 spp.), Microhylidae (2 spp.), Odontophrynidae (1 sp.) and Phyllomedusidae (1 sp.) (Table 2; Figure 4 and Figure 5). Most species (56.7\%, 17 species) have wide distributions in Brazil, occupying different biomes and no endemic species were registered.

The species accumulation curve presented a strong tendency towards stabilization (Figure 6), which suggests that the sampling effort was appropriate for species richness and that the number of species will remain constant regardless of an increase in sampling effort. Furthermore, the observed species richness represented $95.2 \%$ of the richness estimated by Chao $2(31.51 \pm 1.27)$ and $88.8 \%$ of the richness estimated by Jackknife 1 (33.79 \pm 0.93$)$.

We observed low similarities in species composition between different protected areas compared in this study, which was mainly determined by species turnover among areas (93.27\% of total beta diversity). Species loss contributed only $6.72 \%$ of total beta diversity (Figure 7).
In general, we also observed the formation of two clusters, one formed by the Caatinga biome protected areas and another by Cerrado biome protected areas (Figure 8). No single species was common in all protected areas analyzed. However, Rhinella jimi and Leptodactylus troglodytes were common in all Caatinga biome protected areas and Physalaemus cuvieri was common in all Cerrado biome protected areas. Among the 28 protected areas of these biomes, the differences in species composition were mainly caused by Chapada Diamantina National Park $(\mathrm{LCBD}=0.040)$, Raso da Catarina Ecological Station $(\mathrm{LCBD}=0.043)$, Peti Environmental Station ( $\mathrm{LCBD}=0.044)$, and Santuário do Caraça RPPN (LCBD $=0.046)$, which had the highest number of exclusive species $(p . \mathrm{LCBD}<0.05)$.

None of the species registered here were exclusive to Sete Cidades National Park, being recorded in other protected areas of Caatinga and Cerrado biome. We observed that the anurofauna recorded in Sete Cidades National Park is more similar to that recorded in Delta do Parnaíba Environmental Protected Area $\left(\mathrm{J}^{\prime}=0.68\right)$, with 21 species in common, in Ubajara National Park $\left(\mathrm{J}^{\prime}=0.56\right)$, with 18 species in common, and in Lençóis Maranhenses National Park $\left(\mathrm{J}^{\prime}=0.54\right)$, with 15 species in common. Whereas anuran richness registered in Santuário do Caraça RPPN $\left(J^{\prime}=0.07\right)$ and Peti Environmental Station $\left(J^{\prime}=0.11\right)$, both in state of Minas Gerais, with four and five species in common respectively were more distinct from our study (Figure 7). Furthermore, the geographical distance between the protected areas was able to explain the amphibian species composition dissimilarity in the areas investigated $(\mathrm{r}=0.68, p=0.001)$, where the further away are two areas more dissimilarity is their anuran composition. 
Araújo, KC. et al.

The majority of amphibians of Sete Cidades National Park $(90 \%$, 27 species) are classified as 'Least Concern' (LC) according to IUCN Red List Categories and Criteria (IUCN 2020). Conservation status for Scinax gr. ruber was not provided since we did not identify it at the specific level. Rhinella mirandaribeiroi and Adenomera juikitam do not present data on abundance and/or distribution, being classified as data deficient (DD), although the lack of data is not a category of threat.

Table 2. Anuran species found in the Sete Cidades National Park, Piauí state, northeastern Brazil, with their respective authors, voucher, tissue sample, IUCN status and biomes of occurrence (Biome): Caatinga (CA), Cerrado (CE), Atlantic rain forest (AT), Amazon rain forest (AM) and wide distribution (WD). The conservation status of the species was classified according to IUCN (2020): LC (Least Concern), DD (Data Deficient), NA (Not Applicable).

\begin{tabular}{|c|c|c|c|c|}
\hline Taxa (Author) & Voucher & Tissue Sample & IUCN status & Biome \\
\hline \multicolumn{5}{|l|}{ BUFONIDAE } \\
\hline Rhinella jimi (Stevaux, 2002) & URCA-H 14535 & & $\mathrm{LC}$ & WD \\
\hline \multicolumn{5}{|l|}{ HYLIDAE } \\
\hline Boana raniceps (Cope, 1862) & CBPII 035 & URCA-G 2792 & $\mathrm{LC}$ & WD \\
\hline Dendropsophus minutus (Peters, 1872) & CBPII 054 & URCA-G 2774 & $\mathrm{LC}$ & WD \\
\hline Dendropsophus rubicundulus (Reinhardt and Lutken, 2000) & CBPII 051 & URCA-G 2738 & $\mathrm{LC}$ & $\mathrm{CA}, \mathrm{CE}$ \\
\hline Dendropsophus soaresi (Carmaschi and Jim, 1983) & CBPII 046 & & $\mathrm{LC}$ & $\mathrm{AT}, \mathrm{CA}, \mathrm{CE}$ \\
\hline Scinax fuscomarginatus (Lutz, 1925) & CBPII 072 & URCA-G 2741 & LC & WD \\
\hline Trachycephalus typhonius (Linnaeus, 1758) & URCA-H 14508 & URCA-G 2725 & $\mathrm{LC}$ & WD \\
\hline \multicolumn{5}{|l|}{ LEPTODACTYLIDAE } \\
\hline Adenomera juikitam Carvalho and Giaretta, 2013 & CBPII 055 & URCA-G 2788 & DD & $\mathrm{AM}, \mathrm{CA}, \mathrm{CE}$ \\
\hline Leptodactylus fuscus (Schneider, 1799) & CBPII 039 & & $\mathrm{LC}$ & WD \\
\hline Leptodactylus macrosternum (Miranda-Ribeiro 1926) & CBPII 036 & URCA-G 2711 & $\mathrm{LC}$ & WD \\
\hline Leptodactylus cf. mystaceus (Spix, 1824) & CBPII 037 & URCA-G 2796 & $\mathrm{LC}$ & WD \\
\hline Leptodactylus pustulatus (Peters, 1870) & URCA-H 14475 & & $\mathrm{LC}$ & $\mathrm{CA}, \mathrm{CE}$ \\
\hline Leptodactylus syphax Bokermann, 1969 & CBPII 060 & & $\mathrm{LC}$ & WD \\
\hline Pseudopaludicola mystacalis (Cope, 1887) & CBPII 056 & URCA-G 2736 & $\mathrm{LC}$ & WD \\
\hline \multicolumn{5}{|l|}{ MICROHYLIDAE } \\
\hline Dermatonotus muelleri (Boettger, 1885) & URCA-H 14480 & URCA-G 2778 & $\mathrm{LC}$ & WD \\
\hline Elachistocleis piauiensis Caramaschi and Jim, 1983 & CBPII 066 & URCA-G 2751 & $\mathrm{LC}$ & $\mathrm{CA}, \mathrm{CE}$ \\
\hline \multicolumn{5}{|l|}{ ODONTOPHRYNIDAE } \\
\hline Proceratophrys cristiceps (Müller, 1883) & CBPII 067 & URCA-G 2761 & $\mathrm{LC}$ & AT, CA, CE \\
\hline \multicolumn{5}{|l|}{ PHYLLOMEDUSIDAE } \\
\hline Pithecopus nordestinus (Caramaschi, 2006) & CBPII 048 & URCA-G 3079 & $\mathrm{LC}$ & AT, CA, CE \\
\hline
\end{tabular}



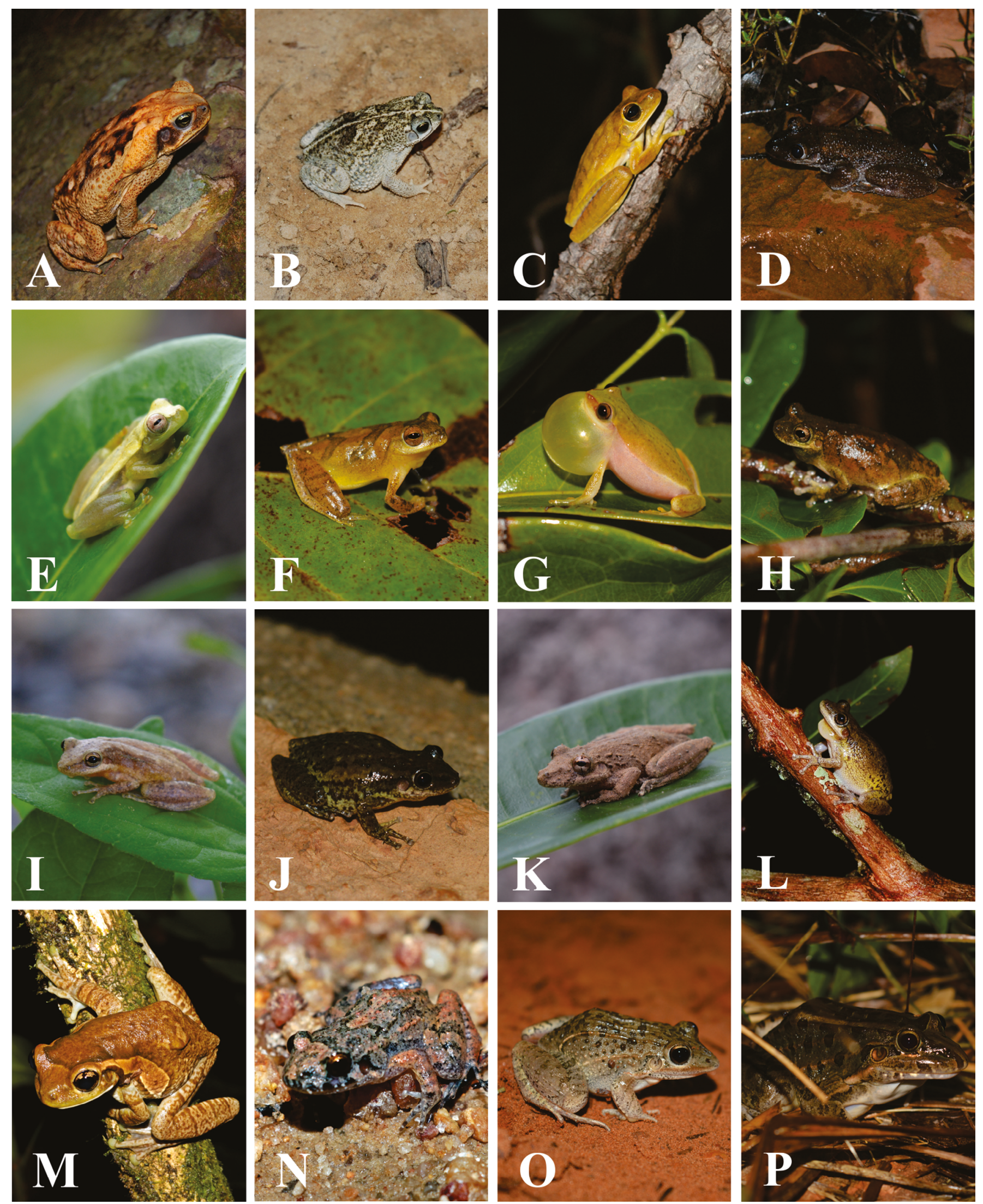

Figure 4. Anurans recorded in the Sete Cidades National Park (SCNP), located in the northern region of Piauí state, northeastern Brazil. A - Rhinella jimi; B - Rhinella mirandaribeiroi; C - Boana raniceps; D - Corythomantis greeningi; E - Dendropsophus minusculus; F - Dendropsophus minutus; G - Dendropsophus rubicundulus; H - Dendropsophus soaresi; I - Scinax fuscomarginatus; J - Scinax gr. ruber; K - Scinax nebulosus; L - Scinax x-signatus; M - Trachycephalus typhonius; N Adenomera juikitam; $\mathrm{O}$ - Leptodactylus fuscus; $\mathrm{P}$ - Leptodactylus macrosternum. 

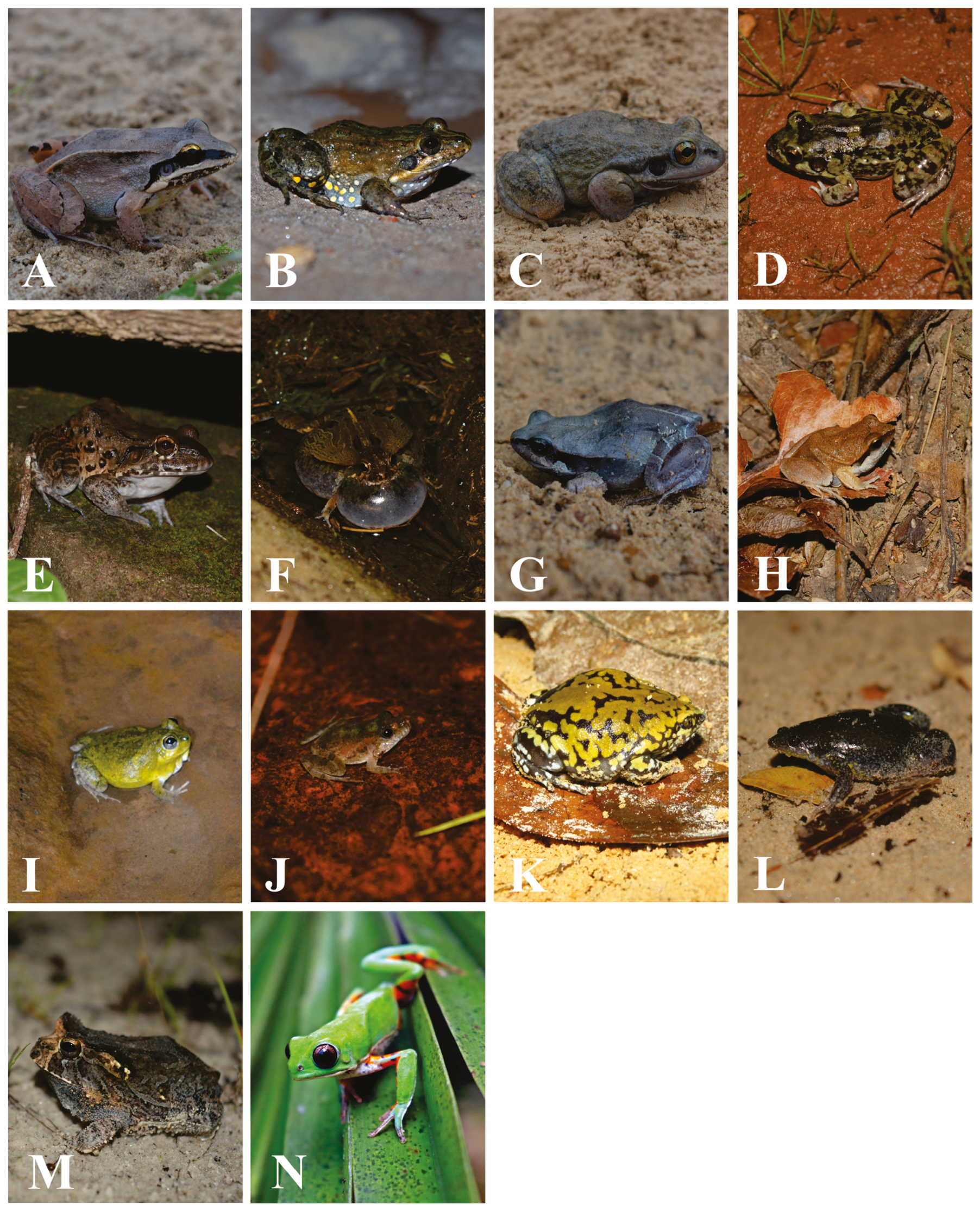

Figure 5. Anurans recorded in the Sete Cidades National Park (SCNP), located in the northern region of Piauí state, northeastern Brazil. A - Leptodactylus cf. mystaceus; B - Leptodactylus pustulatus; C - Leptodactylus syphax; D - Leptodactylus troglodytes; E - Leptodactylus vastus; F - Physalaemus albifrons; G - Physalaemus centralis; H - Physalaemus cuvieri; I - Pleurodema diplolister; J - Pseudopaludicola mystacalis; K - Dermatonotus muelleri; L - Elachistocleis piauiensis; M - Proceratophrys cristiceps; N - Pithecopus nordestinus. 


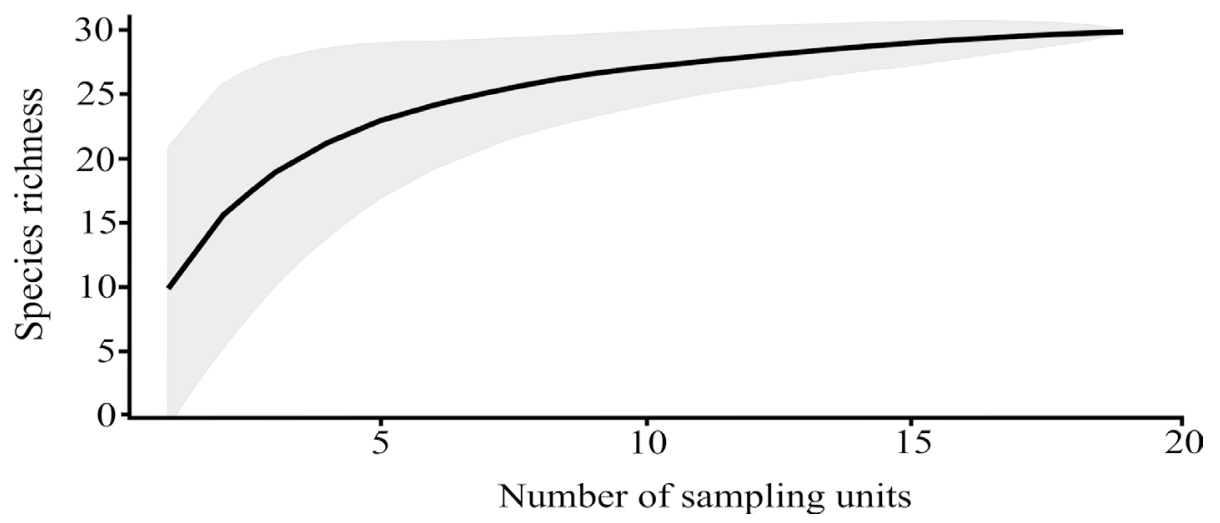

Figure 6. Accumulation curves for anurans sampled in the Sete Cidades National Park (SCNP), Piauí state, northeastern Brazil, based on the number of samples, constructed from 1000 randomizations.

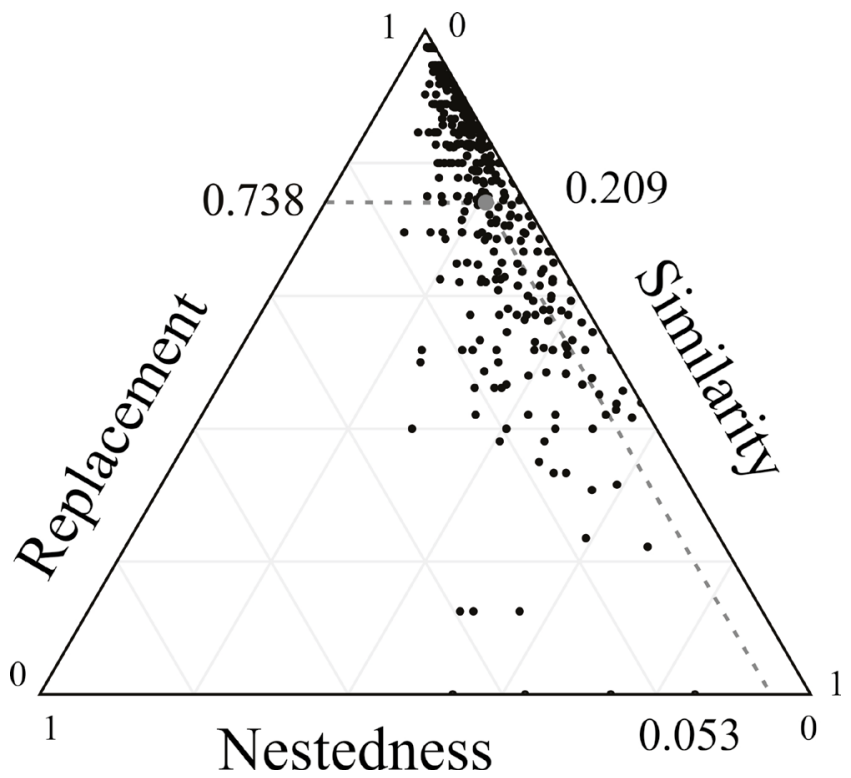

Figure 7. Triangular plot of the beta diversity among Caatinga and Cerrado protected areas, showing the values of similarity, replacement, and nestedness. Each dot represents a pairwise comparison of the selected locations. The dotted lines represent the links between the mean values (gray circle), which are listed on the three axes.

\section{Discussion}

About 55 amphibian species are found in the state of Piauí (Roberto et al. 2013), of which we recorded approximately $54 \%$ in Sete Cidades National Park. This richness was higher than other protected areas of the state, such as Uruçuí-Una Ecological Station (Dal Vechio et al. 2013; 26 species), Delta do Parnaíba Environmental Protection Area in the coastal zone of states of Piauí and Maranhão (Loebmann \& Mai 2008, Andrade et al. 2016, Araújo et al. 2018; 26 species), Serra das Confusões National Park (Dal Vechio et al. 2016; 18 species), and Serra da Capivara National Park (Cavalcanti et al. 2014; eight species). The largest number of species recorded here is probably caused by the location of Sete Cidades National Park, within an area of ecological tension, under the influence of different phytogeographic elements (Cerrado-Caatinga) (Rocha \& Prudente 2010). The ecotonal areas of Caatinga and Cerrado biomes harbor high biodiversity in the state of Piauí, and the anurofauna from these environments is characterized by species typical from each of these domains (Dal Vechio et al. 2016).

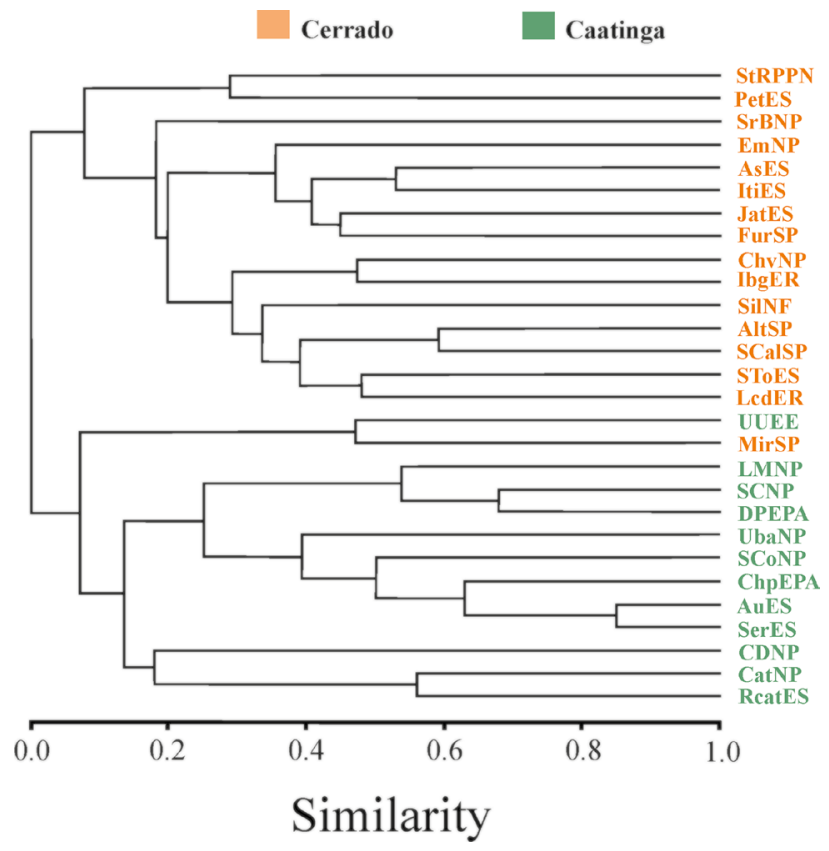

Figure 8. Similarity (Jaccard index and clustering method "UPGMA"; cophenetic correlation coefficient $=0.878$ ) among the anuran species composition in Caatinga and Cerrado protected areas: StRPPN - Santuário do Caraça RPPN; PetES - Peti Environmental Station; SrBNP - Serra da Bodoquena National Park; EmNP Emas National Park; AsES -Assis Ecological Station; ItiES - Itirapina Ecological Station; JatES - Jataí Ecological Station; FurSP - Furnas de Bom Jesus State Park; ChvNP - Chapada dos Veadeiros National Park; IbgER - IBGE Ecological Reserve; SilNF - Silvânia Nacional Forest; AltSP - Altamiro de Moura Pacheco State Park; SCalSP - Serra de Caldas Novas State Park; StoES - Serra Geral do Tocantins Ecological Station; LcdER - Lago do Cedro Extractive Reserve; UUES - Uruçuí-Una Ecological Station; MirSP -Mirador State Park; LMNP - Lençóis Maranhenses National Park; SCNP - Sete Cidades National Park; DPEPA - Delta do Parnaíba Environmental Protection Area; UbaNP - Ubajara National Park; SCoNP - Serra das Confusões National Park; ChpEPA - Chapada do Araripe Environmental Protection Area; AuES - Aiuaba Ecological Station; SerES - Seridó Ecological Station; CDNP - Chapada Diamantina National Park; CatNP - Catimbau National Park; RcatES - Raso da Catarina Ecological Station.

Although there are extensive areas of contact between the two biomes in the state of Piauí, few studies have been conducted in these transitional areas in the state (e.g. Benício et al. 2014, Dal Vechio et al. 2016, this study). Therefore, we highlighted the importance of this study and the Sete Cidades National Park for anuran conservation and preservation. 
Despite the differences in phytogeographic units between Sete Cidades National Park and Serra da Capivara National Park (CapNP), we believe that the great difference observed in the number of species is caused mainly due to sampling problems in SCapNP (Cavalcanti et al. 2014). Only eight amphibian species were recorded in SCapNP, of which seven anurans (Rhinella granulosa, R. jimi, Scinax x-signatus, Leptodactylus syphax, L. troglodytes, L. vastus, Physalaemus cuvieri) and one caecilian (Siphonops sp.), all of them are common of semiarid and open areas of the state of Piaui (Dal Vechio et al. 2013, 2016, Andrade et al. 2016, Araújo et al. 2018), including SCNP. According to Cavalcanti et al. (2014), the low number of species recorded in SCapNP possibly results from the atypical climatic conditions in the region during fieldwork. Seasonal patterns of precipitation, observed in the tropical region, are closely related to the increase in amphibian richness and to the greater number of species in reproductive activity (Vasconcelos \& Rossa-Feres 2005, Vieira et al. 2007). Therefore, it is essential for an efficient anuran sampling, mainly in semiarid regions, that the sampled takes place during the all rainy season.

We identified 181 species of anurans in Caatinga and Cerrado biomes protected areas. This richness is likely higher, considering we only counted species published in the above-cited checklists, and we excluded species without specific identification ("gr.", "aff." and "sp."). Therefore, we would like to underline once again the expressive anuran diversity in these protected areas and in Sete Cidades National Park, since we registered about $17 \%$ of these species. Although direct comparison of species composition might be difficult in some cases due to the use of different collection methods and sampling efforts, SCNP is undeniably a key area of high biological diversity and of central interest for biodiversity protection.

Sete Cidades National Park was more similar to nearby protected areas in Piauí and Maranhão states, in the transition zone between Caatinga and Cerrado biomes. Besides the geographical distance between these areas, the concomitant presence of floristic elements of Caatinga and Cerrado and the similar sampling efforts used may account for their high anuran similarity. Despite most species registered in the present study being widely distributed or occurring in both Caatinga and Cerrado biomes, the formation of two clusters (Caatinga biome protected areas and Cerrado biome protected areas), and the result of our Mantel test suggests that geographic distance might help explain anuran dissimilarity between more distant.

Although we have not registered endemic species and most of them are widespread in Brazilian biomes, some species are distributed predominantly in Caatinga, as Corythomantis greening (Godinho et al. 2013), Rhinella jimi (Stevaux 2002), Pleurodema diplolister (Andrade \& Vaz-Silva 2012), Pithecopus nordestinus (Caramaschi 2006), and Proceratophrys cristiceps (Mângia et al. 2020), or Cerrado biome, as Leptodactylus pustulatus, Rhinella mirandaribeiroi, and Dendropsophus rubicundulus (Roberto et al. 2013). Furthermore, despite the wide distribution of Leptodactylus cf. mystaceus along Brazilian physiognomies (see Andreani et al. 2017, Silva et al. 2020), we present its first record for northern Piauí. This new record increases the geographical distribution of $L$. cf. mystaceus by approximately $548 \mathrm{Km}$, in a straight line, northeast of Ribeiro Gonçalves, the only municipality in Piauí where the species is known to occur (Roberto et al. 2013).
In addition, we filled the distribution gap between the Ibiapaba Plateau, state of Ceará (Loebmann \& Haddad 2010), about $100 \mathrm{~km}$ northeast of the Sete Cidades National Park, and the populations recorded in Mirador State Park, state of Maranhão (Andrade et al. 2017), about $539 \mathrm{~km}$ southwest of SCNP.

Although no SCNP amphibian species has been assessed as "threatened", three species deserve attention. Appropriate data on abundance and/or distribution is lacking for $R$. mirandaribeiroi and Adenomera juikitam, while it is impossible to attribute a conservation status for Scinax gr. ruber, as it was not identified to the specific level and likely correspond to one new species. In addition, an important revision about the species diversity and relationships in the Leptodactylus mystaceus complex reveled as candidate new species $L$. cf. mystaceus from localities near to SCNP (Silva et al. 2020). Therefore, we encourage taxonomic studies addressing these taxa in order to elucidate these questions about possible new anuran species in this protected area.

Habitat loss and fragmentation are important threats to biodiversity (Leal et al. 2005), and the maintenance of preservation areas is critical for environmental protection. Herein, we found a high species diversity in the ecotonal area of the SCNP in Piaui state, with the presence of both widely distributed common species and others predominantly to certain biomes. Although, in theory, amphibian fauna is safe within a protected area, this alone does not prevent population declines from occurring. The increase of amphibian declines worldwide has been attributed to various diseases, including infection by the fungus Batrachochytrium dendrobatidis (Scheele et al. 2019). It is important to highlight this fungus was already detected in northeastern Brazil, sometimes inside some protected areas (e.g. Carvalho et al. 2017, Amorim et al. 2019), close localities to near SCNP in Piauí state (Benício et al. 2019). Therefore, it is also important to investigate the anuran diversity in this protected area considering the amphibian declines worldwide.

This work contributes to the increase in our knowledge of amphibian diversity in the Northeastern region of Brazil. Our results show that SCNP when compared to other protected areas presents the highest anuran species richness in the state of Piaui and one of the two highest among all northeastern National Parks. We reinforce the need for further studies on the natural history, ecology and conservation of amphibians both inside and outside protected areas in Piauí state.

\section{Acknowledgements}

RWA and RAB thank Conselho Nacional de Desenvolvimento Científico e Tecnológico (CNPq) for providing a research fellowship (\# 303622/2015-6; 305988/2018-2; 155556/2018-5). FPS and RAS thank Instituto Federal de Educação, Ciência e Tecnologia (IFPI) for providing the scientific initiation scholarship (\# 141/2018 - PIBIC-IFPI). We are grateful to the $\mathrm{CNPq} / \mathrm{FUNCAP} / \mathrm{CAPES}$ for partial financial support (PROTAX - Processes 440511/2015-1; 5574685/2017; 88882.156872/2016-01), $\mathrm{CNPq} / \mathrm{FUNCAP}$ for financial support for the project "Conservação da Biodiversidade em Nível de Paisagem: mudanças climáticas e distúrbios antropogênicos (Chamada CNPq/ICMBio/FAPs Process 412350/2017-2), and Fundação de Amparo à Pesquisa do Estado do Piauí (FAPEPI) for financial support for publication through the "Programa de Auxílio para Publicação Científica" (edital no 003/2020-FAPEPI). The Instituto Chico Mendes de Conservação da Biodiversidade provided the collecting permit (MMA/ICMBio/SISBIO 61823-1). 


\section{Author Contributions}

Kássio C. Araújo: conception and design, writing, interpretation, and review of the present manuscript.

Etielle B. Andrade: conception and design, writing, interpretation, and review of the present manuscript.

Ana C. Brasileiro: conception and design, writing, interpretation, and review of the present manuscript.

Ronildo A. Benício: conception and design, writing, interpretation, and review of the present manuscript.

Felipe P. Sena: conception and design, writing, interpretation, and review of the present manuscript.

Rayone A. Silva: conception and design, writing, interpretation, and review of the present manuscript.

Antonia Joyce S. Santos: conception and design, writing, interpretation, and review of the present manuscript.

Claylton A. Costa: conception and design, writing, interpretation, and review of the present manuscript.

Robson W. Ávila: conception and design, writing, interpretation, and review of the present manuscript.

\section{Conflicts of Interest}

The authors declare that they have no conflict of interest related to the publication of this manuscript.

\section{Ethics}

We complied with the guidelines established by the ethics committees of our respective research institutions.

\section{Data availability}

We authorized the manuscript publication in public data repositories.

\section{References}

AFONSO, M., ALENCAR, M.R., CASTRO, A.A.J.F., RAMOS-NETO, M.B., MEDEIROS, E.V.S., OLIVEIRA, M.B., BRITO, A.P., SOUSA, A.V., ARAÚJO, D.D., MELO-NETO, J.C., PAZ, J.M.R. \& CARDOSO, P.G. 2008. Parque Nacional de Sete Cidades (PN7C), Piauí: proposta de ampliação. Publ. Avulsas Conserv. Ecossistemas. 19(1):1-36.

AMORIM, F.O., PIMENTEL, L.A., MACHADO, L.F., CAVALCANTI, A.D.C., NAPOLI, M.F. \& JUNCÁ, F.A. 2019. New records of Batrachochytrium dendrobatidis in the state of Bahia, Brazil: histological analysis in anuran amphibian collections. Dis. Aquat. Organ. 136(2):147-155. http://dx.doi. org $/ 10.3354 /$ dao03402

ANDRADE, E.B., GUIMARÃES, R., LEITE JR., J.M.A. \& LEITE, J.R.S.A 2011. Amphibia, Anura, Leptodactylidae, Leptodactylus syphax Bokermann, 1969: Distribution extension and geographic distribution map. Check List. 7(5):592-593. http://dx.doi.org/10.15560/7.5.592

ANDRADE, S.P. \& VAZ-SILVA, W. 20 12. First state record and distribution extension of Pleurodema diplolister (Peters 1870) (Anura: Leiuperidae) from state of Goiás, Brazil. Check List. 8(1):149-151. https://doi. org/10.15560/8.1.149

ANDRADE, E.B., LEITE, J.R.S.A. \& ANDRADE, G.V. 2014. Anurans from the municipality of Ilha Grande, Parnaíba River Delta, Piauí, Northeastern Brazil. Herpetol. Notes. 7(1):219-226.

ANDRADE, E.B., LEITE, J.R.S.A. \& ANDRADE, G.V. 2016. Diversity and distribution of anuran in two islands of Parnaíba River Delta, Northeastern Brazil. J. Bio. Env. Sci. 8(2):74-86.
ANDRADE, E.B., WEBER, L.N. \& LEITE, J.R.S.A. 2017. Anurans of the Parque Estadual do Mirador, a remnant of Cerrado in the state of Maranhão, Northeastern Brazil. Biota Neotrop. 17(4):1-12. https://doi. org/10.1590/1676-0611-bn-2016-0260 (last access in 08/06/2020)

ANDREANI, T.L., BORGES, R.E. \& SOUZA-SANTOS, L.R. 2017. Leptodactylus mystaceus (Spix, 1824): Distribution extension for the Brazilian Cerrado (Anura: Leptodactylidae). Herpetol. Notes. 10(1):435-437.

ANNUNZIATA, B.B., FONTENELE, W.M., CASTRO, I.S., GURGEL, R.F. \& NASCIMENTO, K.A. 2007. Amphibia, Anura, Hylidae, Dendropsophus rubicundulus: Distribution extension. Check List. 3(1):242-243. http:// dx.doi.org/10.15560/7.6.843

ARAUJO, C.D.O., CONDEZ, T.H. \& SAWAYA, R.J. 2009. Anfíbios Anuros do Parque Estadual das Furnas do Bom Jesus, sudeste do Brasil, e suas relações com outras taxocenoses no Brasil. Biota Neotrop. 9(2):77-98. http://dx.doi.org/10.1590/S1676-06032009000200007 (last access in 08/06/2020)

ARAUJO, C. \& ALMEIDA-SANTOS, S.M. 2011. Herpetofauna de um remanescente de cerrado no estado de São Paulo, sudeste do Brasil. Biota Neotrop. 11(3):47-62. https://doi.org/10.1590/S1676-06032011000300003 (last access in 08/06/2020)

ARAÚJO, K.C., GUZZI, A. \& ÁVILA, R.W. 2018. Influence of habitat heterogeneity on anuran diversity in Restinga landscapes of the Parnaíba River delta, Northeastern Brazil. ZooKeys. 757:69-83. https://doi. org/10.3897/zookeys.757.21900

BENÍCIO, R.A., SILVA, G.R. \& FONSECA, M.G. 2011. Amphibia, Anura, Hylidae, Sphaenorhynchus lacteus (Daudin, 1800): First record of the genus and species for the state of Piauí, Brazil. Check List. 7(2):196-197. http:/ dx.doi.org/10.15560/7.2.196

BENÍCIO, R.A., DA SILVA, G.R. \& FONSECA, M.G. 2012. Physalaemus cicada Bokermann, 1966 (Anura: Leiuperidae): Distribution extension. Check List. 8(4):630-631. http://dx.doi.org/10.15560/8.4.630

BENÍCIO, R.A., SILVA, G.R. \& FONSECA, M.G. 2014. Comunidade de anuros em uma área de ecótono no nordeste do Brasil. Bol. Mus. Para. Emílio Goeldi. Cienc. Nat. 9(3):511-517.

BENICIO, R.A., DA SILVA, G.R., FONSECA, M.G. 2015. Anurans from a Caatinga area in Piauí State, northeastern Brazil. Bol. Mus. Biol. Mello Leitão. 37(2):207-217.

BENÍCIO, R.A., CARVALHO, T., BARBOSA, M.D.R., COSTA, J.D.M., SILVA, F.C.C. \& FONSECA, M.G. 2019. Worrying news for Brazilian Caatinga: Prevalence of Batrachochytrium dendrobatidis in Amphibians. Trop. Conserv. Sci. 12:1-6. https://doi.org/10.1177/1940082919892626

BERTOLUCI, J., CANELAS, M.A.S., EISEMBERG, C.C., PALMUTI, C.F.S. \& MONTINGELLI G.G. 2009. Herpetofauna da Estação Ambiental de Peti, um fragmento de Mata Atlântica do estado de Minas Gerais, sudeste do Brasil. Biota Neotrop. 9(1):147-155. https://doi.org/10.1590/S167606032009000100017 (last access in 08/06/2020)

BRASILEIRO, C.A., SAWAYA, R.J., KIEFER, M.C. \& MARTINS, M. 2005. Amphibians of an open cerrado fragment in southeastern Brazil. Biota Neotrop. 5(2):93-109. https://doi.org/10.1590/S1676-06032005000300006 (last access in 08/06/2020)

BRITO, F.A., \& CÂMARA, J.B.D. 1998. Democratização e Gestão ambiental: Em busca do Desenvolvimento Sustentável. Rio de Janeiro: Vozes, $332 \mathrm{p}$.

CALDAS, F.L.S., COSTA, T.B., LARANJEIRAS, D.O., MESQUITA, D.O. \& GARDA, A.A. 2016. Herpetofauna of protected areas in the Caatinga V: Seridó Ecological Station (Rio Grande do Norte, Brazil). Check List. 12(4):1-14. http://dx.doi.org/10.15560/12.4.1929

CANELAS, M.A.S. \& BERTOLUCI, J. 2007. Anurans of the Serra do Caraça, southeastern Brazil: species composition and phenological patterns of calling activity. Iheringia, Sér. Zool. 97(1):21-26. https://dx.doi.org/10.1590/ S0073-47212007000100004

CARAMASCHI, U. 2006. Redefinição do Grupo de Phyllomedusa hypochondrialis, com redescrição de P. megacephala (Miranda-Ribeiro, 1926), revalidação de P. azurea Cope, 1862 e descrição de uma nova espécie (Amphibia, Anura, Hylidae). Arq. Mus. Nac. 64:159-179. 
CARVALHO, T., BECKER, C.G. \& TOLEDO, L.F. 2017. Historical amphibian declines and extinctions in Brazil linked to chytridiomycosis. Proc. R. Soc. Lond. [Biol]. 284(1):2-54. https://doi.org/10.1098/rspb.2016.2254

CARVALHO, T.R.D., MORAES, L.J.C.L., LIMA, A.P., FOUQUET, A., PELOSO, P.L.V., PAVAN, D., DRUMMOND, L.O., RODRIGUES, M.T., GIARETTA, A.A., GORDO, M., NECKEL-OLIVEIRA, S., HADDAD, C.F.B. 2020. Systematics and historical biogeography of Neotropical foamnesting frogs of the Adenomera heyeri clade (Leptodactylidae), with the description of six new Amazonian species. Zoo. J. Linn. Soc. 2020(XX):139. https://doi.org/10.1093/zoolinnean/zlaa051

CASTRO, D.P., MÂNGIA, S., MAGALHÃES, F.D.M., RÖHR, D.L., CAMURUGI, F., SILVEIRA-FILHO, R.R., SILVA, M.M.X., ANDRADEOLIVEIRA, J.A., SOUSA, T.A., FRANÇA, F.G.R., HARRIS, D.J., GARDA, A.A. \& BORGES-NOJOSA, D.M. 2019. Herpetofauna of protected areas in the Caatinga VI: The Ubajara National Park, Ceará, Brazil. Herpetol. Notes. 12(1):727-742.

CASTRO, A.A.J.F. \& COSTA, J.M. 2007. Flora e Melissofauna associada de um Cerrado rupestre da região setentrional do Piauí. In: Programa regional de pós-graduação em Desenvolvimento e Meio Ambiente (Org.). Cerrado Piauiense: Uma Visão Multidisciplinar. Teresina, Editora da Universidade Federal do Piauí. p.271-298.

CAVALCANTI, L.B.Q., COSTA, T.B., COLLI, G.R., COSTA, G.C., FRANÇA, F.G.R., MESQUITA, D.O., PALMEIRA, C.N.S., PELEGRIN, N., SOARES, A.H.B., TUCKER, D.B. \& GARDA, A.A. 2014. Herpetofauna of protected areas in the Caatinga II: Serra da Capivara National Park, Piauí, Brazil. Check List. 10(1):18-27. http://dx.doi.org/10.15560/10.1.18

CHAO, A. \& JOST, L. 2012. Coverage-based rarefaction and extrapolation: standardizing samples by completeness rather than size. Ecology. 93(12):2533-2547. https://doi.org/10.1890/11-1952.1

CHAO, A., GOTELLI, N.J., HSIEH, T.C., SANDER, E.L., MA, K.H., COLWELL, R.K. \& ELLISON, A.M. 2014. Rarefaction and extrapolation with Hill numbers: a framework for sampling and estimation in species diversity studies. Ecol Monogr. 84(1):45-67. https://doi.org/10.1890/13-0133.1

COLLI, G.R., NOGUEIRA, C.C., PANTOJA-LEITE, D.L., LEDO, R.M.D., COSTA, B.M. \& BRANDÃO, R.A. 2011. Herpetofauna da Reserva Ecológica do IBGE e seu entorno. In: RIBEIRO, M.L., editor. Reserv. Ecológica do IBGE. 1st ed. Rio de Janeiro: Instituto Brasileiro de Geografia e Estatística. p.131-145.

COLWELL, R.K., CHAO, A., GOTELLI, N.J., LIN, S.Y., MAO, C.X., CHAZDON, R.L. \& LONGINO, J.T. 2012. Models and estimators linking individual-based and sample-based rarefaction, extrapolation and comparison of assemblages. J. Plant. Ecol. 5(1):3-21. https://doi. org/10.1093/jpe/rtr044

COSTA, T.B., LARANJEIRAS, D.O., CALDAS, F.L.S., SANTANA, D.O., SILVA, C.F., ALCÂNTARA, E.P., BRITO, S.V., GALDINO, J.Y., MESQUITA, D.O., FARIA, R.G., FRANÇA, F.G.R. ÁVILA, R.W., \& GARDA, A.A. 2018. Herpetofauna of protected areas in the Caatinga VII: Aiuaba Ecological Station (Ceará, Brazil). Herpetol. Notes. 11(1):929-941.

CRUMP, M.L. \& SCOTT JR., N.J. 1994. Visual encounter surveys. In Measuring and Monitoring Biological Diversity - Standard Methods for Amphibians. HEYER, W.R., DONNELLY, M.A.R., MCDIARMID, W., HAYEK, L.A.C., FOSTER, M.S. (Eds.), Smithsonian Institution Press, Washington, p.84-91.

DAL VECHIO, F., RECODER, R.S., RODRIGUES, M.T. \& ZAHER, H. 2013. The herpetofauna of the Estação Ecológica de Uruçuí-Una, state of Piauí, Brazil. Pap. Avulsos de Zool. 53(16):225-243. http://dx.doi.org/10.1590/ S0031-10492013001600001

DAL VECHIO, F., TEIXEIRA JR., M., RECODER, R.S., RODRIGUES, M.T. \& ZAHER, H. 2016. The herpetofauna of Parque Nacional da Serra das Confusões, state of Piauí, Brazil, with a regional species list from an ecotonal area of Cerrado and Caatinga. Biota Neotrop. 16(3):e20150105. http:// dx.doi.org/10.1590/1676-0611-BN-2015-0105 (last access in 08/06/2020)

DELLA-FÁVERA, J.C. 2002. Parque Nacional de Sete Cidades, PI-Magnífico monumento natural. In: SCHOBBENHAUS C., CAMPOS D.A., QUEIROZ E.T., WINGE M., BERBERT-BORN M.L.C. (Edits.) Sítios Geológicos e Paleontológicos do Brasil. 1. ed. Brasilia: DNPM/CPRM - Comissão Brasileira de Sítios Geológicos e Paleobiológicos. 1(1):335-342.
DRAY, S., BAUMAN, D., BLANCHET, G., BORCARD, D., CLAPPE, S., GUÉNARD, G., JOMBART, T., LAROCQUE, G., LEGENDRE, P., MADI, M. \& WAGNER, H.H. 2019. Adespatial: Multivariate multiscale spatial analysis. R package version $0.3-3$. https://cran.r-project.org/package=adespatial

ESRI. 2008. ArcGIS Desktop: version 9.3. Redlands, CA: Environmental Systems Research Institute. http://www.esri.com/software/arcgis/index. html (last access in 10/09/2019)

FARIAS, R.R.S. \& CASTRO, A.A.J.F. 2004. Fitossociologia de trechos da vegetação do Complexo de Campo Maior, Campo Maior, PI, Brasil. Acta Bot. Bras. 18(4):949-963. http://dx.doi.org/10.1590/S0102-33062004000400025.

FROST, D.R. 2020. Amphibian Species of the World: an Online Reference. Version 6.1. Electronic Database accessible at http://research.amnh.org/herpetology/ amphibia/index.html. American Museum of Natural History, New York, USA. http://dx.doi.org/10.5531/db.vz.0001 (last access in 15/05/2020)

GARDA, A.A., COSTA, T.B., SANTOS-SILVA, C.R., MESQUITA, D.O., FARIA, R.G., CONCEIÃO, B.M., SILVA, I.R.S., FERREIRA, A.S., ROCHA, S.M., PALMEIRA, C.N.S., RODRIGUES, R., FERRARI, S.F. \& TORQUATO, S. 2013. Herpetofauna of protected areas in the caatinga I: Raso da Catarina Ecological Station (Bahia, Brazil). Check List. 9(2):405414. http://dx.doi.org/10.15560/9.2.405

GODINHO, L.B., MOURA, M.R. \& FEIO, R.N. 2013. New records and geographic distribution of Corythomantis greeningi Boulenger, 1896 (Amphibia: Hylidae). Check List 9(1):148-150. https://doi. org/10.15560/9.1.148

GOTELLI, N.J. \& COLWELL, R.K. 2001. Quantifying biodiversity: procedures and pitfalls in the measurement and comparison of species richness. Ecol. Lett. 4(4):379-391. https://doi.org/10.1046/j.1461-0248.2001.00230.x

IBGE. Instituto Brasileiro de Geografia e Estatística. 2019. Biomas e Sistema Costeiro-Marinho do Brasil. IBGE, Coordenação de Recursos Naturais e Estudos Ambientais, Rio de Janeiro.

ICMBIO. Instituto Chico Mendes de Conservação da Biodiversidade. 2016. Parques Nacionais do Brasil. IBDF. Instituto Brasileiro de Desenvolvimento Florestal. 1979. Plano de Manejo: Parque Nacional de Sete Cidades. Brasília: IBDF-M.A/ Fundação Brasileira para a Conservação da Natureza (FBCN), 61 p.

IUCN. 2020. The IUCN Red List of Threatened Species. Version 2020-1. Electronic Database accessible at https://www.iucnredlist.org. (last access in $15 / 05 / 2020$ )

KINDT, R. \& COE, R. 2005. Tree diversity analysis. A manual and software for common statistical methods for ecological and biodiversity studies. World Agroforestry Centre (ICRAF), Nairobi (Kenya).

KOPP, K., SIGNORELLI, L., BASTOS \& R.P. 2010. Distribuição temporal e diversidade de modos reprodutivos de anfíbios anuros no Parque Nacional das Emas e entorno, Estado de Goiás, Brasil. Iheringia. Ser. Zool. 100(3):192-200. https://dx.doi.org/10.1590/S0073-47212010000300002

LEAL, I.R., SILVA, J.M.C., TABARELLI, M. \& LACHER JR., T.E. 2005. Mudando o curso da conservação da biodiversidade na Caatinga do Nordeste do Brasil. Megadiversidade 1:139-146.

LEGENDRE, P., \& DE CÁCERES, M. 2013. Beta diversity as the variance of community data: dissimilarity coefficients and partitioning. Ecol. Lett. 16(8):951-963. https://doi.org/10.1111/ele.12141

LEGENDRE, P. 2014. Interpreting the replacement and richness difference components of beta diversity. Glob. Ecol. Biogeogr. 23(11):1324-1334. https://doi.org/10.1111/geb.12207

LEITE JR., J.M.A., SAMPAIO, J.M., SILVA-LEITE, R.R., TOLEDO, L.F., LOEBMANN, D. \& LEITE, J.R.S.A. 2008. Amphibia, Anura, Hylidae, Scinax fuscomarginatus: Distribution extension. Check List. 4(4): 475-477. http://dx.doi.org/10.15560/4.4.475

LOEBMANN, D. \& MAI, A.C.G. 2008. Amphibia, Anura, Coastal Zone, Piauí state, Northeastern Brazil. Check List. 4(1):161-170. http://dx.doi. org $/ 10.15560 / 4.2 .161$

LOEBMANN, D. \& HADDAD, C.F.B. Amphibians and reptiles from a highly diverse area of the Caatinga domain: composition and conservation implications. Biota Neotrop. 10(3): http://www.biotaneotropica.org.br/ v10n3/en/abstract?article+bn03910032010 (last access in 08/06/2020) 
LOPES, S.F., VALE, V.S., OLIVEIRA, A.P. \& SCHIAVINI, I. 2011. Análise comparativa da estrutura e composição florística de Cerrado no Brasil Central. Interciência. 36(1):8-15.

MACEDO, R.G., ANDRADE, E.B. \& LEITE, J.R.S.A. 2011. New record and distribution extension of Hypsiboas crepitans (Wied-Neuwied, 1824) (Anura, Hylidae) to the northern part of the state of Piauí, Brazil. Revista CEPSUL - Bio e Conserv. Mar. 2(1):30-33.

MACIEL, A.O., LEITE, J.M., LEITE, R.R.S., LEITE, J.R.S.A. \& CASCON, P. 2015. A New Species of Chthonerpeton Peters 1880 (Amphibia: Gymnophiona: Typhlonectidae) from the State of Piauí, Northeastern Brazil. J. Herpetol. 49(2):308-313. https://doi.org/10.1670/13-067

MAGALHÃES, F.M., DANTAS, A.K.B.P., BRITO, M.R.M., MEDEIROS, P.H.S., OLIVEIRA, A.F., PEREIRA, T.C.S.O., QUEIROZ, M.H.C., SANTANA, D.J., SILVA, W.P. \& GARDA, A.A. 2013. Anurans from an Atlantic Forest Caatinga ecotone in Rio Grande do Norte State, Brazil. Herpetol. Notes. 6(1):1-10.

MAGALHÃES, M.F., LARANJEIRAS, D.O., COSTA, T.B., JUNCÁ, F.A., MESQUITA, D.O., RÖHR, D.L., SILVA, W.P., VIEIRA, G.H.C. \& GARDA, A.A. 2015. Herpetofauna of protected areas in the Caatinga IV: Chapada Diamantina National Park, Bahia, Brazil. Herpetol. Notes. 8(1):243-261.

MAGURRAN, A.E. \& MCGILL, B.J. 2011. Biological diversity: frontiers in measurement and assessment. Oxford University Press.

MÂNGIA, S., OLIVEIRA, E.F., SANTANA, D.J., KOROIVA, R., PAIVA, F. \& GARDA, A.A. 2020. Revising the taxonomy of Proceratophrys MirandaRibeiro, 1920 (Anura: Odontophrynidae) from the Brazilian semiarid Caatinga: Morphology, calls and molecules support a single widespread species. J. Zool. Syst. Evol. Res. 2020(00):1-22. https://doi.org/10.1111/jzs. 12365

MANLY, B.F.J. 1994. Multivariate statistical methods: a primer, 2nd ed. New York: Chapman \& Hall.

MARTINS, R.A. \& ASSALIM, A.M. 2019. First record of Trachycephalus nigromaculatus (Amphibia, Anura, Hylidae) in the state of Piauí, Brazil. Check List. 15(3):411-414. https://doi.org/10.15560/15.3.411

MATAVELLI, R, CAMPOS, A.M., SANTOS, C.L. \& ANDRADE, G.V. 2019 Anuran community in a Neotropical natural ecotone. Herpetol. Notes. 12(1):1145-1156.

MATOS, M.Q. \& FELFILI, J.M. 2010. Florística, fitossociologia e diversidade da vegetação arbórea nas matas de galeria do Parque Nacional de Sete Cidades (PNSC), Piauí, Brasil. Acta Bot. Bras. 24(2):483-496. http://dx.doi org 1 10.1590/S0102-33062010000200019

MELO, M., FAVA, F., PINTO, H.B.A., BASTOS, R.P. \& NOMURA, F. 2013 Diversidade de Anuros (Amphibia) na reserva extrativista Lago do Cedro e seu entorno, Aruanã, Goiás. Biota Neotrop. 13(2): 205-217. https://doi. org/10.1590/S1676-06032013000200020

MIRANDA, J.P. 2007. Ecologia e Conservação da Herpetofauna do Parque Nacional dos Lençóis Maranhenses, Maranhão, Brasil. Tese de Doutorado, Universidade Estadual de Campinas.

MORAIS, A.R., BASTOS, R.P., VIEIRA, R. \& SIGNORELLI, L. 2012. Herpetofauna of the Floresta Nacional de Silvânia, a Cerrado remnant in Central Brazil. Neotrop. Biol. Conserv. 7(2):114-121. http://dx.doi. org/10.4013/nbc.2012.72.05

OKSANEN, J., BLANCHET, F.G., KINDT, R. LEGENDRE, P., MINCHIN, P.R., O'HARA, R.B., SIMPSON, G.L., SOLYMOS, P., STEVENS, M.H.H. \& WAGNER, H. 2016. Vegan: Community Ecology Package. R package version 2.3-3. https://CRAN.R-project.org/package=vegan (Last access in 11/09/2019).

OLIVEIRA, M.E.A., FARIAS, R.R.S., CASTRO, A.A.J. \& MARTINS, F.R. 2010 Classificação e caracterização dos tipos vegetacionais do Parque Nacional de Sete Cidades, Piauí, Brasil. Biodivers. Ecót. Reg. Setentr. Piauí. 5(1):66-89

PRADO, V., SILVA, F., DIAS, N., PIRES, J. \& ROSSA-FERES, D. 2009. Anura, Estação Ecológica de Jataí, São Paulo state, southeastern Brazil. Check List. 5(3):495-502. http://dx.doi.org/10.15560/5.3.495

PEDROSA, I.M.M.C., COSTA, T.B., FARIA, R.G., FRANC, A, F.G.R., LARANJEIRAS, D.O., PEREIRA, T.C.S.O., PALMEIRA, C.N.S., TORQUATO, S., MOTT, T., VIEIRA, G.H.C. \& GARDA, A.A. Herpetofauna of protected areas in the Caatinga III: The Catimbau National Park, Pernambuco, Brazil. Biota Neotrop. 14(4):e20140046. http://dx.doi. org/10.1590/1676-06032014004614 (last access in 08/06/2020)
PINA, L., MORAIS, A. \& PRADO, C. 2015. Rhinella mirandaribeiroi (Gallardo, 1965) (Amphibia: Anura: Bufonidae): distribution extension and new state record. Check List. 11(3):1654. http://dx.doi.org/10.15560/11.3.1654

RAMALHO, W.P., FRANÇA, D.P.F., GUERRA, V., MARCIANO, R., VALE, N.C.D. \& SILVA, H.L.R. 2018. Herpetofauna of Parque Estadual Altamiro de Moura Pacheco: one of the last remnants of seasonal forest in the core region of the Brazilian Cerrado. Papéis Avul. de Zool. 58:1-12. http://dx.doi. org/10.11606/1807-0205/2018.58.51

RAMALHO, W.P., JORGE, R.F., GUIMARÃES, T.V., PIRES, R.A., PEÑA, A.P. \& GUERRA, V. 2019. Structure and regional representativeness of the herpetofauna from Parque Estadual da Serra de Caldas Novas, Cerrado, Central Brazil. Neotropical Biodiversity 5(1):10-21. https://doi.org/10.108 0/23766808.2019.1583305

RIBEIRO, J.F. \& WALTER, B.M.T. 1998. Fitofisionomias do bioma Cerrado. In Cerrado: ambiente e flora. SANO, S.M. \& ALMEIDA, S.P. (Ed.). Cerrado: ambiente e flora. EMBRAPA CPAC, Planaltina, p.89-166.

RIBEIRO-JÚNIOR, J.W. \& BERTOLUCI, J. 2009. Anuros do cerrado da Estação Ecológica e da Floresta Estadual de Assis, sudeste do Brasil. Biota Neotrop. 9(1):207-216. https://doi.org/10.1590/S1676-06032009000100020 (last access in 08/06/2020)

RIBEIRO, S.C., ROBERTO, I.J., SALES, D.L., ÁVILA, R.W. \& ALMEIDA, W.D.O. 2012. Amphibians and reptiles from the Araripe bioregion, northeastern Brazil. Salamandra. 48(3):133-146.

ROBERTO, I.J., RIBEIRO, S.C. \& LOEBMANN, D. 2013. Amphibians of the state of Piauí, Northeastern Brazil: a preliminary assessment. Biota Neotrop. 13(1):322-330. http://www.biotaneotropica.org.br/v13n1/en/abstract?inven tory+bn04113012013 (last access in 08/06/2020)

ROCHA, W.A. \& PRUDENTE, A.L.C. 2010. The Snake Assemblage of Parque Nacional de Sete Cidades State of Piauí, Brazil. J. Herpetol. 5(2):132-143. https://doi.org/10.2994/057.005.0207

SANTORO, G.R.C.C. \& BRANDÃO, R.A. 2014. Reproductive modes, habitat use, and richness of anurans from Chapada dos Veadeiros, central Brazil North-West J. Zool. 10(2):365-373.

SANTOS, A.J.S., COSTA, C.A., SENA, F.P., ARAÚJO, K.C. \& ANDRADE, E.B. 2019. New record and geographic distribution of Proceratophrys caramaschii Cruz, Nunes, and Juncá, 2012 in the state of Piauí, Northeastern Brazil (Anura: Odontophrynidae). Herpetol. Notes. 12(1):675-679.

SCHEELE, B.C., PASMANS, F., BERGER, L., SKERRATT, L.F., MARTEL, A., BEUKEMA, W., ACEVEDO, A.A., BURROWES, P.A., CARVALHO, T., CATENAZZI, A., DE LA RIVA, I., FISHER, M.C., FLECHAS, S.V., FOSTER, C.N., FRÍAS-ÁLVAREZ, P., GARNER, T.W.J., GRATWICKE, B., GUAYASAMIN, J.M., HIRSCHFELD, M., KOLBY, J.E., KOSCH, T.A., LA MARCA, E., LINDENMAYER, D.B., LIPS, K.R., LONGO, A.V., MANEYRO, R., MCDONALD, C.A.,MENDELSON, III J., PALACIOSRODRIGUEZ, P., PARRA-OLEA, G., RICHARDS-ZAWACKI, C.L., RÖDEL, M.O., ROVITO, S.M., SOTO-AZAT, C., TOLEDO, L.F., VOYLES, J., WELDON, C., WHITFIELD, S.M., WILKINSON, M., ZAMUDIO, K.R. \& CANESSA, S. 2019. Amphibian fungal panzootic causes catastrophic and ongoing loss of biodiversity. Science. 363(1):14591463. http://doi.org/10.1126/science.aav0379

SILVA, A., JÚNIOR, S. \& ZINA, J. 2013. Checklist of amphibians in a transitional area between the Caatinga and the Atlantic Forest, central-southern Bahia, Brazil. Check List. 9(4):725-732. http://dx.doi.org/10.15560/9.4.725

SILVA, L.A., MAGALHÃES, F.M., THOMASSEN, H., LEITE, F.S., GARDA, A.A., BRANDÃO, R.A., HADDAD, C.F., GIARETTA, A.A. \& CARVALHO, T.R. 2020. Unraveling the species diversity and relationships in the Leptodactylus mystaceus complex (Anura: Leptodactylidae), with the description of three new Brazilian species. Zootaxa. 4779(2):151-189. http://dx.doi.org/10.11646/zootaxa.4779.2.1

STEVAUX, M.N. 2002. The new specie of Bufo (Anura, Bufonidae) in Northeastern Brazil. Rev. Bras. Zool. 19:235-242.

UETANABARO, M., SOUZA, F.L., LANDGREF-FILHO, P., BEDA, A.F. \& BRANDÃO, R.A. 2007. Anfíbios e répteis do Parque Nacional da Serra da Bodoquena, Mato Grosso do Sul, Brasil. Biota Neotrop. 7(3):279289. https://doi.org/10.1590/S1676-06032007000300030 (last access in $08 / 06 / 2020$ ) 
VAlduJO, P.H., RECODER, R.S., VASCONCELlOS, M.M. \& PORTELLA, A.S. 2009. Amphibia, Anura, São Desidério western Bahia uplands, northeastern Brazil. Check List. 5(4):903-911. http://dx.doi. org/10.15560/5.4.903

VASCONCELOS, J.P., SOUSA, G.L., LEITE, J.R.S.A. \& ANDRADE, E.B. 2014. New record and geographic distribution map of Physalaemus centralis (Anura: Leptodactylidae), in Piauí, Northeastern Brazil. Herpetol. Notes. 7(1):325-327.
VASCONCELOS, T.S. \& ROSSA-FERES, D.C. 2005. Diversidade, distribuição espacial e temporal de anfíbios anuros (Amphibia, Anura) na região noroeste do estado de São Paulo, Brasil. Biota Neotrop. 5(2):137-150. https://doi. org/10.1590/S1676-06032005000300010 (last access in 08/06/2020)

VIEIRA, W.L.S., ARZABE, C. \& SANTANA, G.G. 2007. Composição e distribuição espaço-temporal de anuros no Cariri Paraibano, nordeste do Brasil. Oecol. Bras. 11(3):383-396.

Received: 09/06/2020

Revised: $13 / 08 / 2020$

Accepted: 25/08/2020

Published online: 05/10/2020 